University of Nebraska - Lincoln

DigitalCommons@University of Nebraska - Lincoln

U.S. Environmental Protection Agency Papers

U.S. Environmental Protection Agency

2003

\title{
In Situ Abiotic Detoxification and Immobilization of Hexavalent Chromium
}

Faruque A. Khan

U.S. Environmental Protection Agency, khan.faruque@epa.gov

Robert W. Puls

U.S. Environmental Protection Agency

Follow this and additional works at: https://digitalcommons.unl.edu/usepapapers

Khan, Faruque A. and Puls, Robert W., "In Situ Abiotic Detoxification and Immobilization of Hexavalent Chromium" (2003). U.S. Environmental Protection Agency Papers. 137.

https://digitalcommons.unl.edu/usepapapers/137

This Article is brought to you for free and open access by the U.S. Environmental Protection Agency at DigitalCommons@University of Nebraska - Lincoln. It has been accepted for inclusion in U.S. Environmental Protection Agency Papers by an authorized administrator of DigitalCommons@University of Nebraska - Lincoln. 


\title{
In Situ Abiotic Detoxification and Immobilization of Hexavalent Chromium
}

\author{
by Faruque A. Khan and Robert W. Puls
}

\begin{abstract}
Detailed site characterization data from the former electroplating shop at the U.S. Coast Guard Air Support Center, Elizabeth City, North Carolina, suggested that the elevated $\mathrm{Cr}(\mathrm{VI})$ in the capillary fringe area had contaminated the ground water at the site. Most of the mobile $\mathrm{Cr}(\mathrm{VI})$ is present in the capillary fringe zone of the aquifer under an oxidizing environment. Current literature suggests that the reduction of $\mathrm{Cr}(\mathrm{VI})$ to $\mathrm{Cr}(\mathrm{III})$ through in situ redox manipulation in the presence of a reductant is an innovative technique for remediating chromate-contaminated sediments and ground water. The objective of this study was to evaluate the effectiveness of sodium dithionite in creating a reductive environment to remediate $\mathrm{Cr}(\mathrm{VI})$ present in soil. Sodium dithionite, a strong reductant, was injected into a small area of the vadose zone where elevated $\mathrm{Cr}(\mathrm{VI})$ was identified. Several striking changes observed in the target zone during the post-injection monitoring periods include a significant decrease in Eh(SHE), as much as $\sim 700 \mathrm{mV}$, absence of dissolved oxygen for 48 weeks, and the increase of $\mathrm{Fe}(\mathrm{II})$ concentrations. Results indicated that the in situ remedial treatment of $\mathrm{Cr}(\mathrm{VI})$ in the capillary fringe area was effective and consequently the concentration of $\mathrm{Cr}(\mathrm{VI})$ in ground water dropped below the MCLG level. This research demonstrated the effectiveness of in situ abiotic remediation by reducing $\mathrm{Cr}(\mathrm{VI})$ concentrations, mobility, and toxicity in soils and ground water within a short period of time. Therefore, sodium dithionite would be a feasible and cost-effective option for a full-scale remedial approach for the contaminated site at the U.S. Coast Guard Facility.
\end{abstract}

\section{Introduction}

Chromium is widely used in many industrial applications and has resulted in accidental or improper discharge of $\mathrm{Cr}(\mathrm{VI})$ waste into many soil and ground water systems. Chromium is one of the transition metals and may exist in valence state varying from-2 to +6 . Under natural environment, $\mathrm{Cr}(\mathrm{III})$ and $\mathrm{Cr}(\mathrm{VI})$ are the two most stable oxidation states (Barlett and James 1988). The oxyanions of $\mathrm{Cr}(\mathrm{VI})$ are acutely toxic and mutagenic, soluble over a wide $\mathrm{pH}$ range, and very mobile in most neutral and alkaline subsurface environment (Barlett 1991; Palmer and Wittbrodt 1991). In contrast, Cr(III) has relatively low toxicity and is virtually immobile, largely because it precipitates as chromic or mixed $\mathrm{Cr}-\mathrm{Fe}$ oxyhydroxide phases (James 1996; Palmer and Puls1994).

Poor waste management practices of the chrome plating facility at the U.S. Coast Guard (USCG) Support Center, near Elizabeth City, North Carolina, resulted in the release of chromic acid through a hole in the concrete floor into the underlying geologic materials immediately below the plating shop's foundation. A detailed characterization of the underlying geologic materials and ground water of the chrome-plating shop was performed to provide information on the extent of contamination at the site and the potential for off-site migration and environmental impact (Paul et al. 1999). Results indicate that the maximum $\mathrm{Cr}(\mathrm{VI})$ concentrations occur between a depth of 1.5 to 3.0 feet below the ground surface and that these oxyanions are static at these depths but the elevated concentrations of $\mathrm{Cr}(\mathrm{VI})$ in the capillary fringe zone ( $\sim 4.0$ to 6.0 feet) are very mobile owing to the fluctuating water table. The ground water table ranges from 5.0 to 7.0 feet below the ground surface. Historical data of MW-12 suggests that the $\mathrm{Cr}(\mathrm{VI})$ present in the capillary fringe zone have contaminated the ground water and the concentrations of $\mathrm{Cr}(\mathrm{VI})$ were above the National Drinking Water Standards (Khan and Puls 1999). The release of Cr(VI) from this source area has also created a plume of ground water containing dissolved $\mathrm{Cr}(\mathrm{VI})$ which extended from the electroplating shop toward the Pasquotank River. In 1996, a permeable reactive barrier of zero-valent iron was installed to intercept and remediate the ground water plume contaminated with $\mathrm{Cr}(\mathrm{VI})$ (Puls et al. 1999a). This reactive barrier technique is an effective method in reducing and immobilizing $\mathrm{Cr}(\mathrm{VI})$ present in the ground water plume, but it has limited effectiveness to reduce contaminants present in the source area as sorbed phases in the vadose zone. An in situ remedial approach for the source area remediation becomes necessary to complement the permeable reactive batrier in achieving a full-scale site cleanup.

Use of traditional techniques like pump-and-treat to remediate $\mathrm{Cr}(\mathrm{VI})$ in the subsurface environment presents challenges because $\mathrm{Cr}(\mathrm{VI})$ can remain either trapped between low permeability zones or as sorbed phases with sesquioxides and 


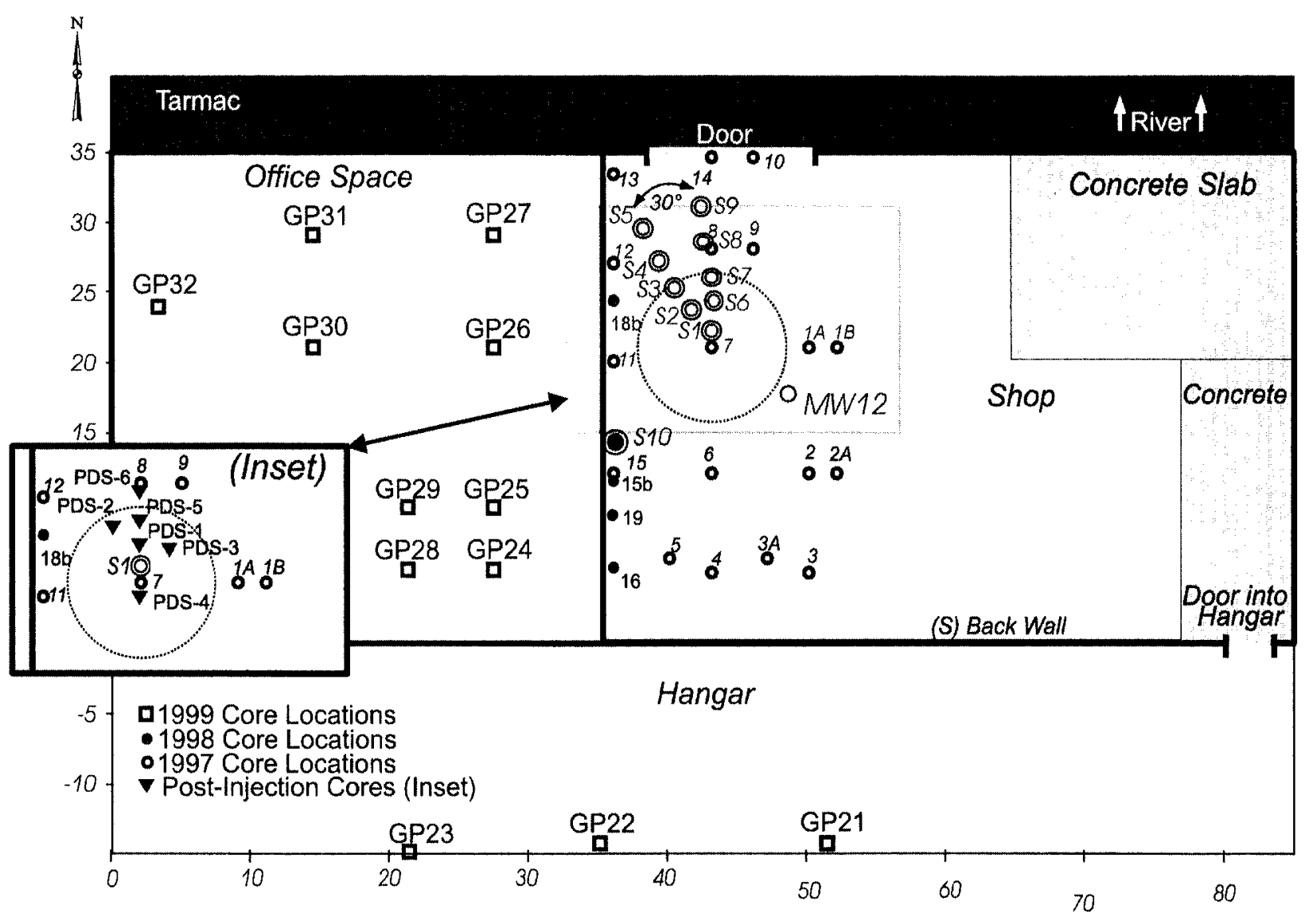

Figure 1. Target area for reductive zone, and ground water and post-injection sampling schemes inside the former electroplating shop.

silicate minerals of the aquifer materials. Yin and Allen (1999) reviewed several innovative in situ remedial strategies recently being developed in remediating ground water and sediment contaminated with chromium compounds. Innovative technique like in situ reduction of $\mathrm{Cr}$ (VI) to $\mathrm{Cr}$ (III) through electron transfer mechanisms in the presence of suitable reductants (electron donors) pose less environmental risk by minimizing the exposure to hazardous materials. This technology is also believed to be faster and more effective for detoxifying and immobilizing contaminants in soil and ground water systems. Several studies have evaluated a number of inorganic and organic reductants to remediate containment $\mathrm{Cr}$ (VI) to $\mathrm{Cr}$ (III). Eary and Rai (1988) and Amonette et al. (1994) postulated that the reduction of $\mathrm{Cr}(\mathrm{VI})$ resulted in the hydroxide solid solution composition of $\mathrm{Cr}_{X} \mathrm{Fe}_{1-\mathrm{X}}(\mathrm{OH})_{3}$ or $\mathrm{Cr}(\mathrm{OH})_{3}$. The irreversible and low solubility hydroxides of $\mathrm{Cr}$ (III) surface inhibits potential reoxidation in two ways: It is a redox stable sink for oxidizable, soluble $\mathrm{Cr}$ (III) and it forms a physical barrier between aqueous $\mathrm{Cr}$ (III) and Mn surfaces (Fendorf 1995).

A number of reductants were used in screening the reduction of $\mathrm{Cr}(\mathrm{VI})$ to $\mathrm{Cr}$ (III) with the aquifer materials from the source area (Khan and Puls 1999). The results of the laboratory experiments suggest that sodium dithionite was effective in remediating $\mathrm{Cr}(\mathrm{VI})$ present in the sediments of the capillary fringe zone. Recent literature also indicates that sodium dithionite has potential to remediate ground water contaminated with chromium, uranium, technetium, and some chlorinated solvents (Amonette et al. 1994; Fruchter 2000).
Therefore, a pilot-scale field test was completed to manipulate the redox condition of the capillary fringe zone with sodium dithionite solution. The purpose of this field study in the former plating shop was to apply sodium dithionite by injecting it into a capillary fringe zone where elevated $\mathrm{Cr}(\mathrm{VI})$ has been identified. The objectives of this pilot project were: (1) to evaluate the effectiveness of sodium dithionite as a reducing agent under field conditions; (2) to examine the impact on $\mathrm{Cr}(\mathrm{VI})$ present in the capillary fringe zone sediments and ground water; (3) to evaluate the solubility and mobility of selected RCRA metals caused by reductant treatment; and (4) to evaluate the potential of sodium dithionite for full-scale site remediation.

\section{Materials and Methods}

\section{Site Geology}

The heterogeneous surficial sediments underneath the former plating shop consist of typical Atlantic coastal plain sediments. The geologic cross section at the injection point resembles the overall underlying geologic materials of the plating shop. An upper layer of nonnative sandy fill material is underlain by silt loam, which overlies a layer of clay loam that ranges from 3.0 to 6.0 feet in thickness and is interbedded with a discontinuous pocket of coarse sand. Below the clay loam layer, there are thin layers of medium- and coarse-textured materials, which extend to 7.0 feet below the ground surface and overlie a layer 

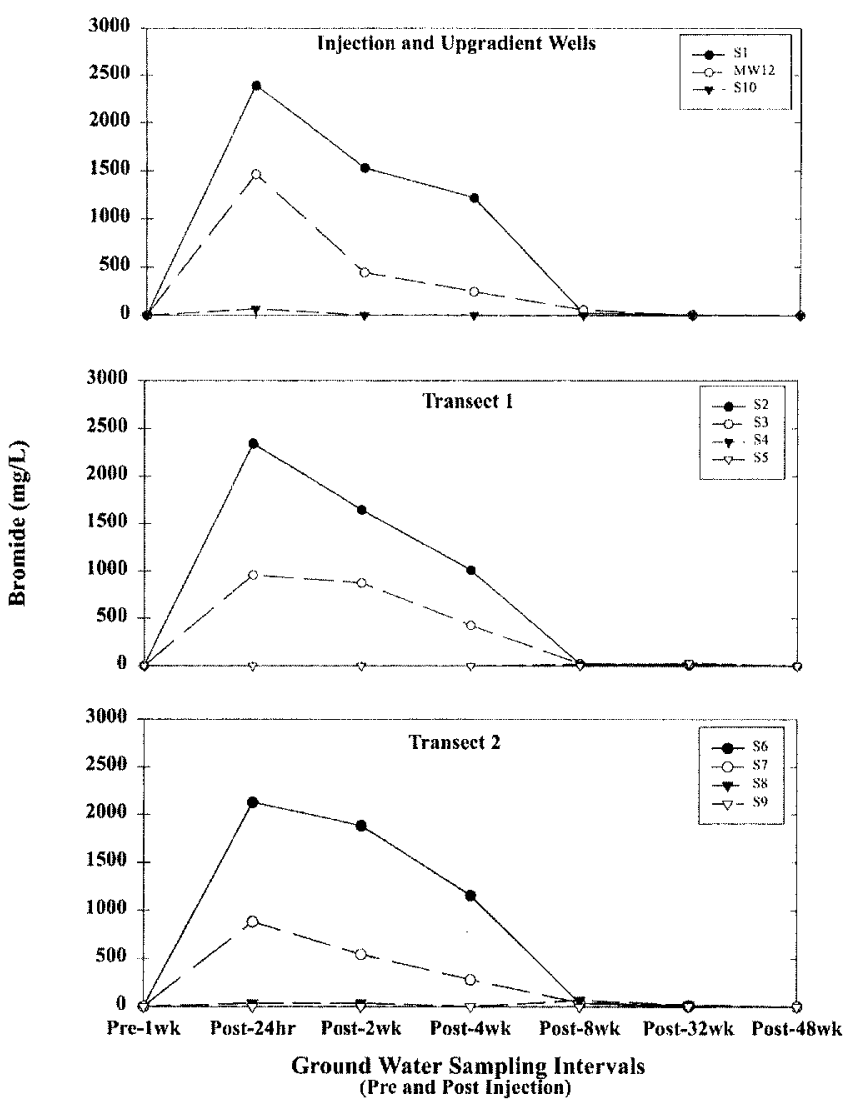

Figure 2. Bromide concentrations in ground water samples during periodic monitoring.

of coarse-textured sand that extends $\sim 13$ feet below the ground surface. The location and the hydrogeology of the site have been described in detail elsewhere (Puls et al. 1994)

\section{Sodium Dithionite Injection}

Personnel from the National Risk Management Research Laboratory, Subsurface Protection and Remediation Division of the U.S. Environmental Protection Agency, in cooperation with U.S. Coast Guard personnel, conducted the field study in July 1999. The target area for remediation was a section in the vadose zone at 4 to 8 feet below the soil surface and $\sim 3.0$ feet $(1 \mathrm{~m})$ in radius. A reducing agent consisting of $0.05 \mathrm{M}$ sodium dithionite $\left(\mathrm{Na}_{2} \mathrm{~S}_{2} \mathrm{O}_{4}\right)$ buffered with $0.1 \mathrm{M}$ potassium bicarbonate $\left(\mathrm{KHCO}_{3}\right)$ and a tracer $0.025 \mathrm{M}$ potassium bromide $(\mathrm{KBr})$ was injected in an existing 2-inch I.D. injection well (S1), 8 feet deep and screened from 4.0 to 8.0 feet, inside the electroplating shop (Figure 1). The total volume of liquid reductant was $\sim 495$ gallons (1874 L). The reducing agent was continuously injected through a centrifugal pump into the injection well under pressure $(\sim 3$ psi) at a flow rate of 0.264 gallon $(1 \mathrm{~L})$ per minute over a 38-hour period. Total estimates of chemicals used in the field study were 495 U.S. gallons (1874 L) of distilled and deionized water, 37.4 pounds $(17 \mathrm{~kg})$ of sodium dithionite $\left(\mathrm{Na}_{2} \mathrm{~S}_{2} \mathrm{O}_{4}\right), 41.8$ pounds $(19 \mathrm{~kg})$ of potassium bicarbonate $\left(\mathrm{KHCO}_{3}\right)$, and 12.4 pounds $(5.63 \mathrm{~kg})$ of bromide tracer $(\mathrm{KBr})$.
Table 1

Periodic Concentrations of Dissolved Oxygen Measured with a Chemet Test Kit

\begin{tabular}{|c|c|c|c|c|c|c|c|}
\hline \multirow[b]{2}{*}{$\begin{array}{l}\text { Monitoring } \\
\text { Wells }\end{array}$} & \multirow[b]{2}{*}{$\begin{array}{c}\text { Pre- } \\
\text { injection }\end{array}$} & \multicolumn{6}{|c|}{ Periodic Monitoring } \\
\hline & & $\begin{array}{c}24 \\
\text { hours }\end{array}$ & $\begin{array}{c}2 \\
\text { weeks }\end{array}$ & $\begin{array}{c}4 \\
\text { weeks }\end{array}$ & $\begin{array}{c}8 \\
\text { weeks }\end{array}$ & $\begin{array}{c}32 \\
\text { weeks }\end{array}$ & $\begin{array}{c}48 \\
\text { weeks }\end{array}$ \\
\hline & & \multicolumn{6}{|c|}{ Concentration of dissolved oxygen $(\mathrm{mg} / \mathrm{L})$} \\
\hline S1 & $>1.00$ & NA & ND & ND & 0.05 & ND & ND \\
\hline S2 & $>1.00$ & NA & 0.40 & 0.20 & $<0.05$ & ND & ND \\
\hline S3 & $>1.00$ & NA & 0.40 & 0.70 & $<0.05$ & ND & ND \\
\hline S4 & $>1.00$ & NA & $>1.00$ & $>1.00$ & $>1.00$ & $>1.00$ & $>1.00$ \\
\hline S5 & 1.00 & NA & 1.00 & $>1.00$ & $>1.00$ & $>1.00$ & $>1.00$ \\
\hline S6 & $>1.00$ & NA & ND & 0.20 & $<0.05$ & ND & ND \\
\hline S7 & $>1.00$ & NA & 0.25 & 0.30 & $<0.05$ & ND & ND \\
\hline S8 & 1.00 & NA & 0.80 & $>1.00$ & $>1.00$ & $>1.00$ & $>1.00$ \\
\hline S9 & 0.70 & NA & 0.80 & 0.90 & NA & $>1.00$ & $>1.00$ \\
\hline S10 & $>1.00$ & $\mathrm{NA}$ & 0.90 & 0.80 & $\mathrm{NA}$ & $>1.00$ & NA \\
\hline MW12 & $>1.00$ & $\mathrm{NA}$ & 0.20 & 0.40 & $<0.05$ & $>1.00$ & NA \\
\hline
\end{tabular}

\section{Ground Water Monitoring Network}

Ten monitoring wells, including up- and downgradient wells, were used to monitor the site. Eight 1/2-inch ID 10-footdeep downgradient monitoring wells (S2, S3, S4, S5, S6, S7, S8, S9) were divided into two transects (Figure 1). The wells were screened from 4 to 10 feet. Ground water characteristics were also monitored in the upgradient MW12 and S10 wells and the injection well (S1). Ground water monitoring wells were monitored inside the electroplating shop one week prior to the injection in order to provide background levels of contaminants and geochemical characteristics of the ground water. Monitoring of these wells was continued during the injection and at 24 hours, two weeks, four weeks, eight weeks, 32 weeks, and 48 weeks following the injection experiment.

\section{Ground Water Analyses}

Ground water samples were collected with a peristaltic pump using low-flow purging techniques (Puls and Powell 1992). All samples were collected following equilibration of water quality parameters (Eh, pH, specific conductance, and temperature). Millivolt readings were converted to Eh using the electrode reading and standard potential of $\mathrm{Ag} / \mathrm{AgCl}$ electrode (SHE) at a given temperature. Puls et al. (1999b) described the standard methods used in performing the following analyses. Analyses for $\mathrm{Cr}(\mathrm{VI})$, ferrous iron (II), dissolved sulfide $\left(\mathrm{S}^{2}\right)$, dissolved oxygen (DO), specific conductance, temperature, $\mathrm{pH}$, redox potential (Eh), alkalinity, and turbidity were performed in the field. The $\mathrm{Cr}(\mathrm{VI}), \mathrm{S}^{2-}$, and $\mathrm{Fe}(\mathrm{II})$ were analyzed colorimetrically with a UV/VIS spectrophotometer. DO was measured using a Chemets ${ }^{\text {(1) }}$ test kit. Conductivity and temperature measurements were made using an ORION $^{\oplus}$ conductivity probe and meter. Eh and $\mathrm{pH}$ measurements were made using redox and a $\mathrm{pH}$ electrode. Alkalinity measurements were made by titration with standardized $\mathrm{H}_{2} \mathrm{SO}_{4}$ acid using a $\mathrm{Hach}^{\sqrt{3}}$ titrator. Turbidity was measured with a $\mathrm{Hach}^{\circledast}$ turbidimeter. Collected ground water samples were analyzed for RCRA metals and cations using an inductively coupled plasma (ICP) based on the EPA standard method 


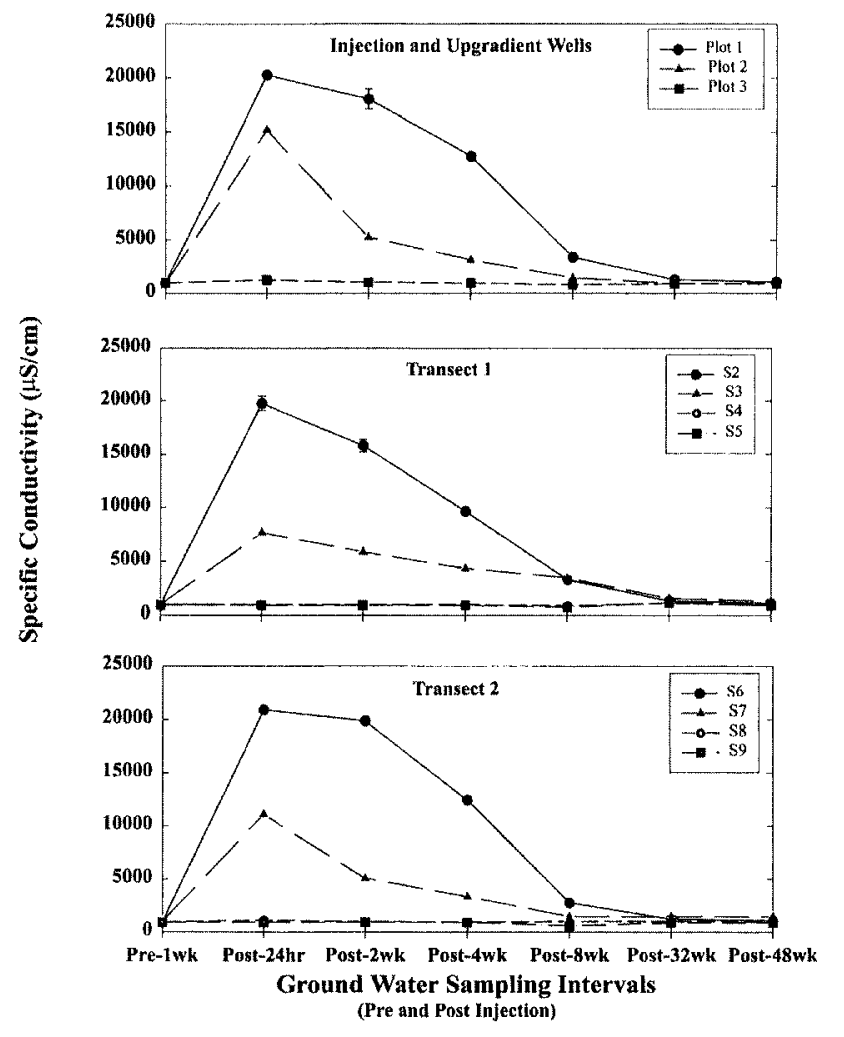

Figure 3. Specific conductivities in ground water samples during periodic monitoring.

6010B and anions (sulfate, chloride, and bromide) using a capillary electrophoresis (CE) based on the EPA standard method 6500 .

\section{Post-Injection Soil Samples}

After the treatment period, six sediment cores around the radial target zone were collected using Geoprobe ${ }^{\circledR}$ sampling equipment to evaluate $\mathrm{Cr}$ (VI) concentrations and the effectiveness of the reductant in the capillary fringe zone sediment. The inset in Figure 1 shows the locations of six soil cores that were collected inside the electroplating shop. Four cores (PDS-1, PDS-2, PDS-3, and PDS-4) were collected within 48 hours of the injection experiment. PDS-1, PDS-2, PDS-3 soil samples were collected from the treatment zone on the downgradient side and PDS-4 was collected from the upgradient side at the edge of the treatment zone. Two other downgradient cores (PDS-5 and PDS-6) were collected eight weeks later, following the injection experiment. PDS-5 was collected from inside the treatment zone and PDS-6 was collected from outside the treatment zone. All the cores were divided into 6-inch sections, air dried and homogenized. Duplicate samples from each section were used to determine the Cr(VI) concentrations in sediments using a modified method of James et al. (1995).

\section{Results and Discussions}

Selected geochemical parameters of ground water were evaluated one week prior to the reductant injection. Results indicate that pre-injection conductivity, $\mathrm{Eh}(\mathrm{SHE})$, and $\mathrm{pH}$ values were relatively uniform beneath the shop with average values of $950(\mathrm{~S} / \mathrm{cm}, 450 \mathrm{mV}$, and 6.5 , respectively. No ferrous iron was
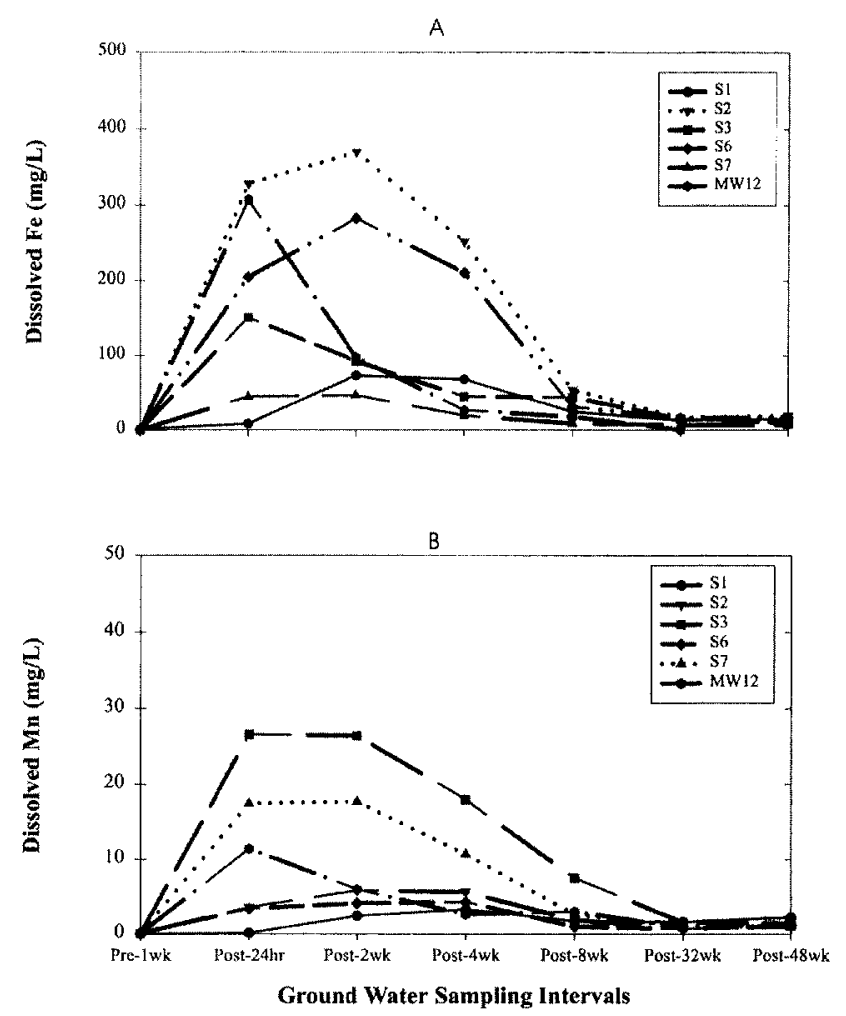

Figure 4. Dissolved Fe and Mn concentrations in ground water samples during periodic monitoring.

detected in any of the wells, while Cr(VI) values ranged from 1.25 to $7.25 \mathrm{mg} / \mathrm{L}$. The pre-injection dissolved oxygen concentrations in the monitoring wells were $\geq 1.00 \mathrm{mg} / \mathrm{L}$ except monitoring well S9 (Table 1).

Background concentrations of $\mathrm{Br}^{-}$in ground-water samples were measured to establish a baseline to determine when breakthrough occurred. Breakthrough of the injected solution was determined when increased $\mathrm{Br}^{-}$concentrations were detected in the monitoring wells. Within two to three hours, elevated concentrations of $\mathrm{Br}^{-}$were observed in monitoring wells $\mathrm{S} 2$ and $\mathrm{S} 6$. The radial distance of these two wells is within a half-meter from the injection well. It took another several hours (eight to 10 hours) for $\mathrm{Br}$ to reach the entire target area. The pre- and postinjection concentrations of $\mathrm{Br}^{-}$along the two transects and the upgradient wells are presented in Figure 2. Post-injection monitoring data show that the increased levels of $\mathrm{Br}^{-}$did arrive at variable concentrations in all the targeted treatment zone monitoring wells, while the concentrations of $\mathrm{Br}^{-}$remained at background levels outside the target zone in the monitoring wells (S4, $\mathrm{S} 5, \mathrm{~S} 8, \mathrm{~S} 9$, and $\mathrm{S} 10$ ). These data suggest that the radius of influence of the injected solution was $\sim 1 \mathrm{~m}$.

Pre-injection specific conductance of the ground water samples was $\sim 950 \mu \mathrm{S} / \mathrm{cm}$. Following the injection, specific conductance significantly increased in the monitoring wells inside the target zone (Figure 3). They continued to rise up greater than $20,000 \mu \mathrm{S} / \mathrm{cm}$ in the $\mathrm{S} 2$ and $\mathrm{S} 6$ monitoring wells observed during the 24-hour post-injection monitoring period. At the same time, the specific conductivity was $<10,000$ $\mu \mathrm{S} / \mathrm{cm}$ in the $\mathrm{S} 3$ and $\mathrm{S} 7$ monitoring wells inside the treatment zone. Dissolved constituents such as ferrous iron, manganese, and sulfate ions and other major constituents of the 

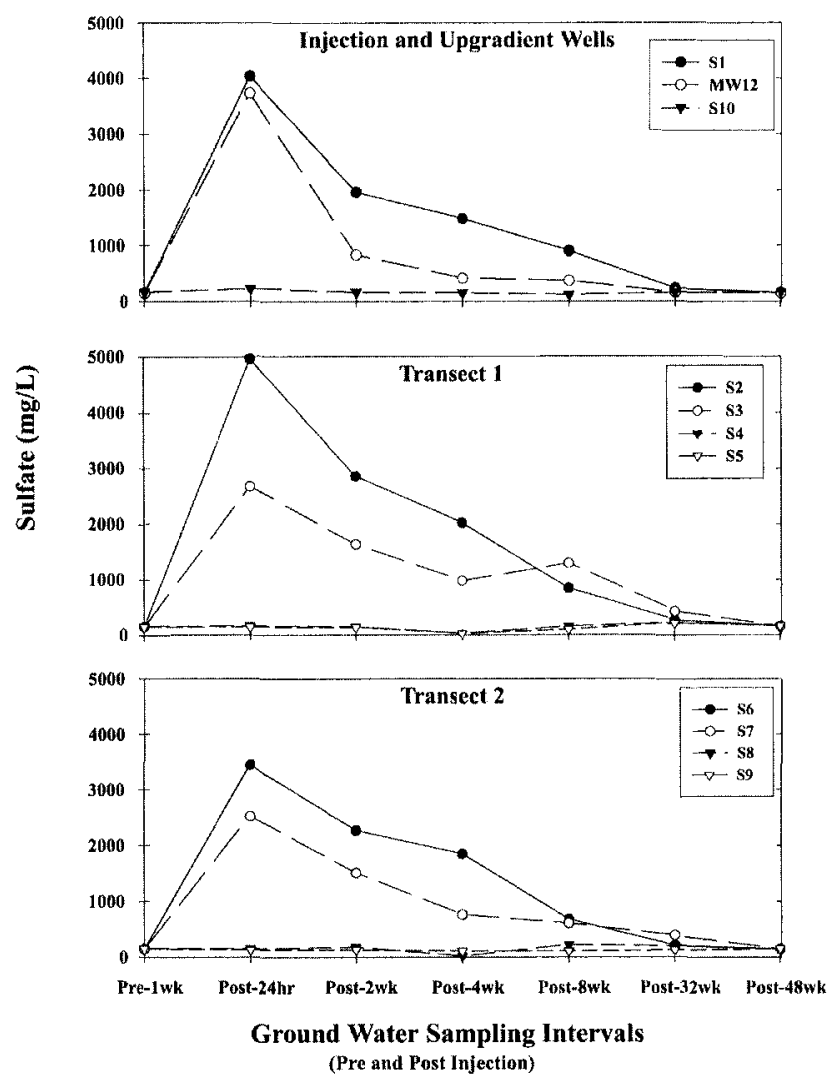

Figure 5. Concentrations of sulfate in ground water samples during periodic monitoring.

injected solution such as $\mathrm{Na}, \mathrm{K}$, and $\mathrm{Br}$ may have contributed to the increased specific conductivity of the ground water. Figures 4 and 5 illustrate the variations in concentrations of iron, manganese, and sulfate ions among ground water samples collected from the monitoring wells. A decreasing trend of these constituents was observed in the subsequent monitoring periods. At the 48-week monitoring period, dissolved iron, manganese, and sulfate, as well as specific conductivity, decreased but remained slightly higher than pre-injection levels inside the treatment zone.

The pre-injection ground water $\mathrm{pH}$ and $\mathrm{Eh}(\mathrm{SHE})$ ranged from 6.1 to 6.8 and 410 to $445 \mathrm{mV}$, respectively. Figure 6 indicates that ground water $\mathrm{pH}$ was stable after the injection period and
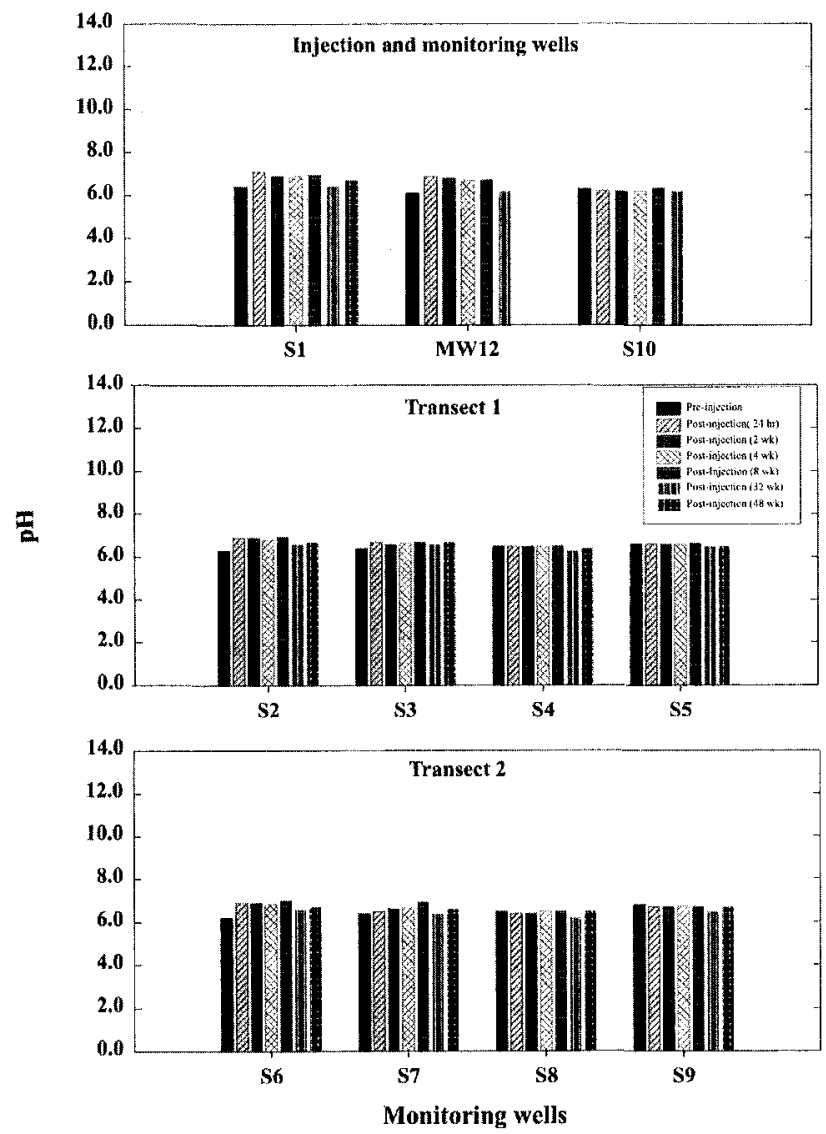

Figure 6. Ground water pH during the monitoring periods.

remained in the range of near neutral to slight alkaline. $\mathrm{A} \mathrm{KHCO}_{3}$ buffered reductant solution was used to maintain a near neutral to alkaline $\mathrm{pH}$ condition in the treatment zone. Maintaining a neutral to alkaline $\mathrm{pH}$ was important because adsorption of chromate ions on clay particles decreases under neutral and higher $\mathrm{pH}$. The injected reductant considerably affected the redox condition in the treatment zone. A significant difference in redox environments is reflected in the data for the various monitoring wells within the target zone (Figure 7). The Eh(SHE) in ground water was significantly lower than the pre-injection $\mathrm{Eh}(\mathrm{SHE})$ values in the radial treatment zone. The DO concentrations were less than 0.40

Table 2

Mean Concentrations of RCRA Metals in Ground Water Samples of Downgradient Monitoring Wells Inside the Treatment Zone

\begin{tabular}{|c|c|c|c|c|c|c|c|}
\hline \multirow[b]{2}{*}{ RCRA Metals } & \multirow[b]{2}{*}{ Pre-injection } & \multicolumn{6}{|c|}{ Post-injection } \\
\hline & & 24 hours & 2 & 8 & 32 & 48 & MCL \\
\hline & \multicolumn{7}{|c|}{ Concentration $(\mu \mathrm{g} / \mathrm{L})$} \\
\hline $\mathrm{Ag}$ & BLQ & BLQ & $5.6(2.4)$ & $2.6(1.1)$ & BLQ & BLQ & 100.0 \\
\hline As & BLQ & BLQ & BLQ & BLQ & BLQ & BLQ & 50.0 \\
\hline $\mathrm{Ba}$ & $52.4(4.5)$ & $418.3(420.1)$ & $147.8(161.4)$ & $227.2(314.3)$ & $110(64.9)$ & $115.7(90.5)$ & 2000 \\
\hline $\mathrm{Cd}$ & $3.43(2.8)$ & $1.59(1.2)$ & $14.7(13.4)$ & $9.00(9.4)$ & $4.30 \cdot(2.1)$ & $4.0(1.7)$ & 5.0 \\
\hline $\mathrm{Hg}$ & NA & NA & NA & $\mathrm{NA}$ & NA & NA & 2.0 \\
\hline $\mathrm{Pb}$ & BLQ & BLQ & BLQ & BLQ & BLQ & BLQ & 15.0 \\
\hline $\mathrm{Se}$ & BLQ & BLQ & BLQ & BLQ & BLQ & BLQ & 50.0 \\
\hline \multicolumn{8}{|c|}{$\begin{array}{l}\text { MCL = Maximum contaminant level } \\
\mathrm{BLQ}=\text { Below quantitation limit } \\
\mathrm{NA}=\text { Not analyzed } \\
\text { Numbers in parentheses are standard deviation }\end{array}$} \\
\hline
\end{tabular}



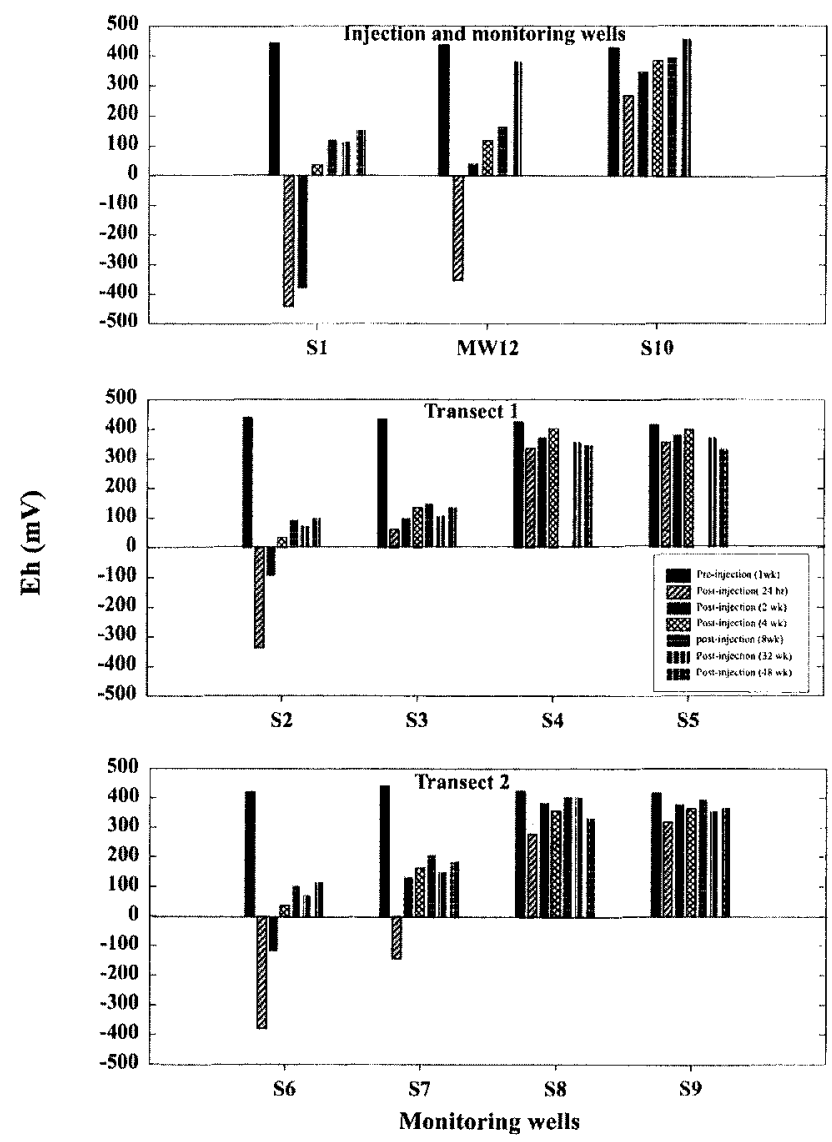

Figure 7. Ground water Eh(SHE) during the monitoring periods.

$\mathrm{mg} / \mathrm{L}$ (Table 1) and the presence of $\mathrm{Fe}$ (II) in the treatment zone ascertained an anoxic environment in the treatment zone. Throughout the monitoring period, monitoring wells (S2 and S6) near the injection well maintained lower redox conditions compared to other monitoring wells inside the target zone. The reductant may have been progressively losing its reactivity as it traveled the radial distance. The Eh(SHE) values outside the target zone remained close to the background levels.

The $\mathrm{Cr}(\mathrm{VI})$ concentrations in the ground water samples within the reduced zone were below the detection limit $(0.01$
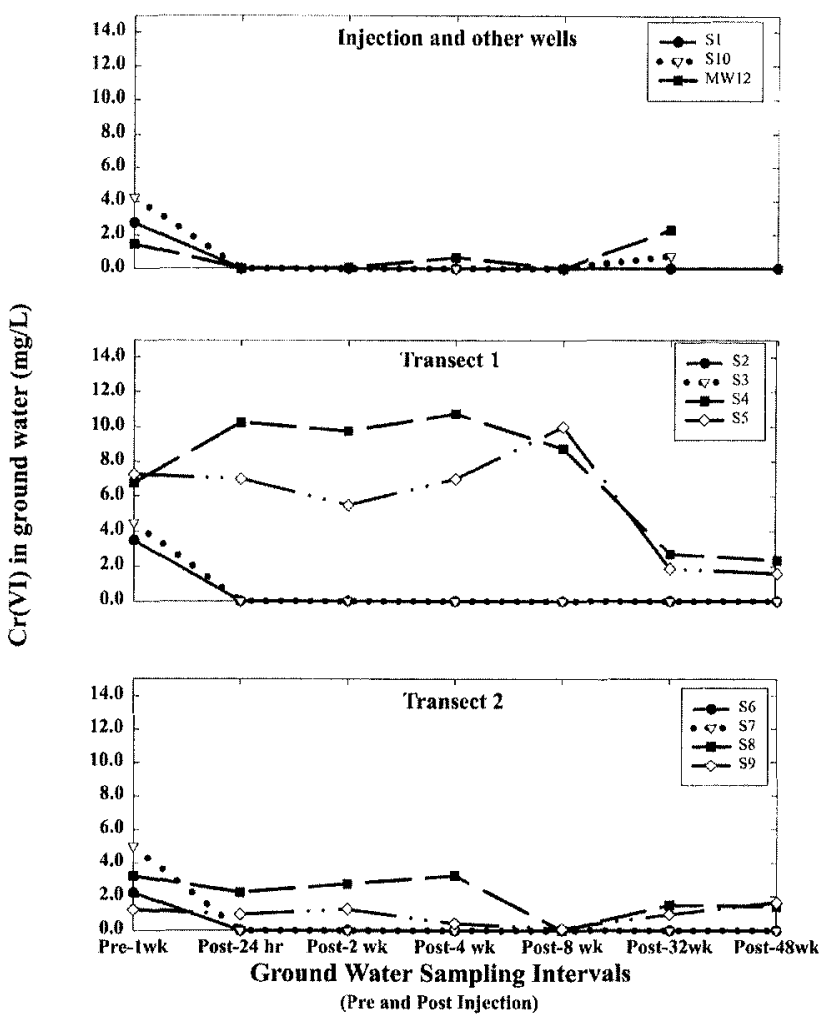

Figure 8. Concentrations of $\mathrm{Cr}(\mathrm{VI})$ in ground water samples during the mo

$\mathrm{mg} / \mathrm{L}$ ) following the injection (Figure 8). The $\mathrm{Cr}(\mathrm{VI})$ concentrations also remained below the detection limit during the subsequent sampling events. A significant amount of dissolved iron was detected in the post-injection ground water samples, suggesting that secondary iron is being reduced and liberated from the solid phases into the ground water. The dissolved iron, presumably $\mathrm{Fe}$ (II) liberated by the reductant, provides the reduction and precipitation of $\mathrm{Cr}$ (VI) to $\mathrm{Cr}(\mathrm{III})$ while the sulfate ions byproducts of $\mathrm{Na}_{2} \mathrm{~S}_{2} \mathrm{O}_{4}$ facilitate an anion exchange reaction to displace sorbed $\mathrm{Cr}(\mathrm{VI})$ from the aquifer materials. In reducing environment, $\mathrm{Cr}$ (III) readily precipitate to form $\mathrm{Cr}(\mathrm{OH})_{3}$. However, the reduction of $\mathrm{Cr}(\mathrm{VI})$ to $\mathrm{Cr}(\mathrm{III})$, coupled with the oxidation of $\mathrm{Fe}$ (II) to $\mathrm{FE}$ (III), leads to the precipitation of a mixed $\mathrm{Cr}-\mathrm{FE}$ hydroxide phase at a wide range of $\mathrm{pH}$

\section{Table 3}

Mean Concentrations of RCRA Metals in Ground Water Samples of Downgradient Monitoring Wells Outside the Treatment Zone

\begin{tabular}{|c|c|c|c|c|c|c|c|}
\hline \multirow[b]{2}{*}{ RCRA Metals } & \multirow[b]{2}{*}{ Pre-injection } & \multicolumn{6}{|c|}{ Post-injection } \\
\hline & & 24 hours & 2 & 8 & 32 & 48 & MCL \\
\hline & \multicolumn{7}{|c|}{ Concentration $(\mu \mathrm{g} / \mathrm{L})$} \\
\hline $\mathrm{Ag}$ & BLQ & BLQ & 1.0 & BLQ & BLQ & BLQ & 100.0 \\
\hline As & BLQ & BLQ & BLQ & BLQ & BLQ & BLQ & 50.0 \\
\hline $\mathrm{Ba}$ & $44.7(5.4)$ & $54.0(.9 .9)$ & $40.8(6.4)$ & $56.8(33.6)$ & $60.8(17.3)$ & $58.8(16.3)$ & 2000 \\
\hline $\mathrm{Cd}$ & 3.20 & $1.17(0.9)$ & $1.25(0.5)$ & $2.66(1.5)$ & $2.0(1.4)$ & $3.0(1.3)$ & 5.0 \\
\hline $\mathrm{Hg}$ & NA & NA & NA & NA & $\mathrm{NA}$ & NA & 2.0 \\
\hline $\mathrm{Pb}$ & BLQ & BLQ & BLQ & BLQ & BLQ & BLQ & 15.0 \\
\hline $\mathrm{Se}$ & BLQ & BLQ & BLQ & BLQ & BLQ & BLQ & 50.0 \\
\hline
\end{tabular}

MCL $=$ Maximum contaminant level

$\mathrm{BLQ}=$ Below quantitation limit

NA $=$ Not analyzed

Numbers in parentheses are standard deviation. 

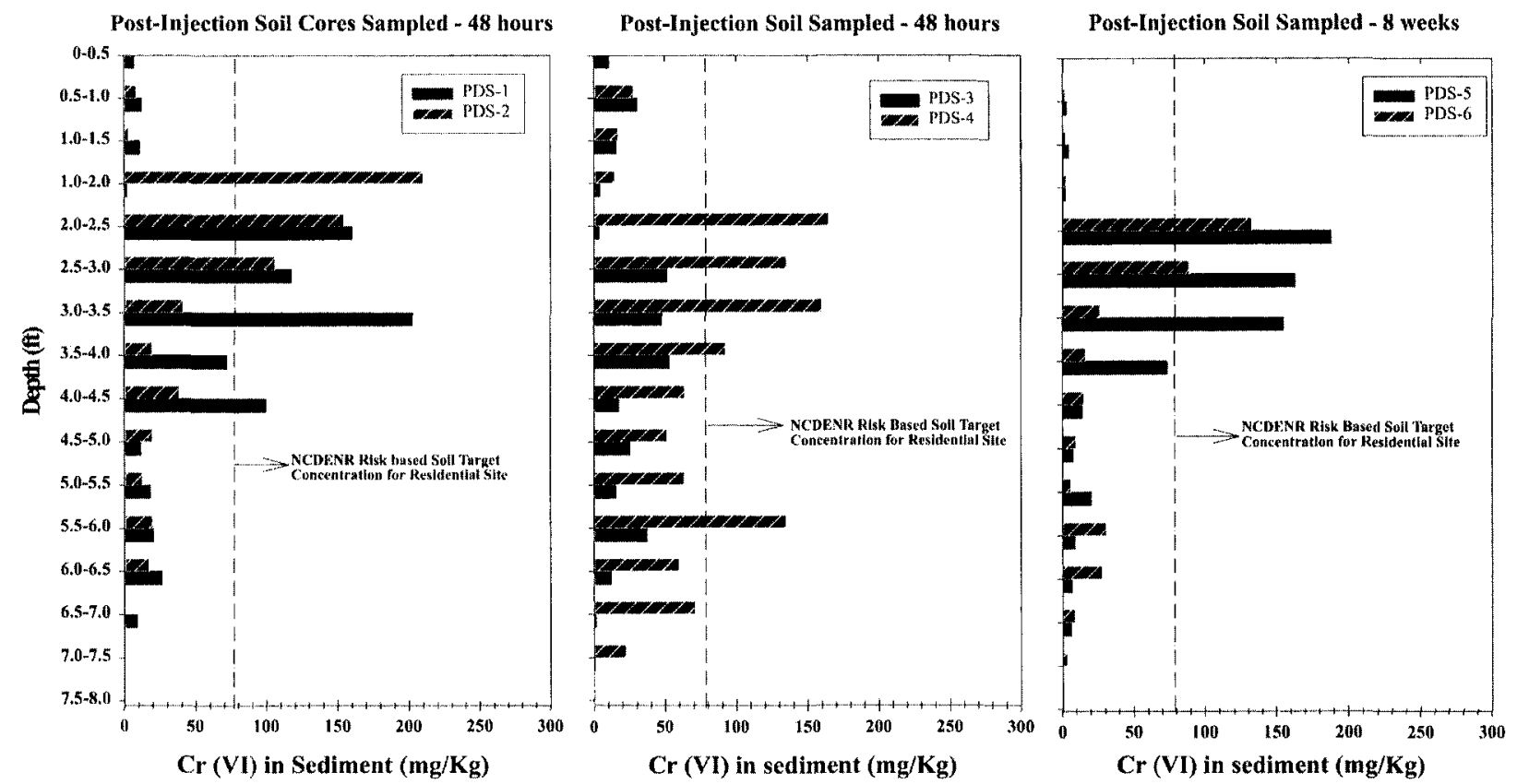

Figure 9. Post-injection $\mathrm{Cr}(\mathrm{VI})$ concentrations in soil samples from the shop area.

(Eary and Rai 1988; Sass and Rai 1987). The following reactions show the potential stoichiometry of the in situ chemical reduction of $\mathrm{Cr}(\mathrm{VI})$ to $\mathrm{Cr}(\mathrm{III})$ in presence of $\mathrm{Fe}^{2+}$.

$$
\begin{aligned}
& \mathrm{CrO}_{4}{ }^{2-}+3 \mathrm{Fe}^{2+}+4\left(\mathrm{OH}^{-}\right)+4 \mathrm{H}_{2} \mathrm{O} \rightarrow \mathrm{Cr}(\mathrm{OH})_{3}+3 \mathrm{Fe}(\mathrm{OH})_{3} \\
& \mathrm{CrO}_{4}{ }^{2-}+3 \mathrm{Fe}^{2+}+4\left(\mathrm{OH}^{-}\right)+4 \mathrm{H}_{2} \mathrm{O} \rightarrow 4\left(\mathrm{Cr}_{0.25} \mathrm{Fe}_{0.75}\right)(\mathrm{OH})_{3}
\end{aligned}
$$

In addition, the structural $\mathrm{Fe}(\mathrm{III})$ within the layer silicate minerals may have been reduced in the treatment zone to an insoluble $\mathrm{Fe}(\mathrm{II})$, creating a spatially fixed reducing condition for continued $\mathrm{Cr}(\mathrm{VI})$ reduction. The potency of $\mathrm{Na}_{2} \mathrm{~S}_{2} \mathrm{O}_{4}$ in reducing $\mathrm{Fe}(\mathrm{III})$ in the silicate minerals was demonstrated by Komadel et al. (1990) and Gan et al. (1992). In transect 1, lower $\mathrm{Cr}(\mathrm{VI})$ concentrations in ground water from the monitoring wells outside the target zone were also observed during the last sampling event. In contrast, concentrations of $\mathrm{Cr}$ (VI) in the monitoring wells outside the upgradient and transect 2 treatment zone were variable.

During the post-injection monitoring, several sets of ground water samples from all 10 monitoring wells and the injection well were collected and analyzed for the RCRA metals (As, Ba, $\mathrm{Cu}, \mathrm{Cd}, \mathrm{Ni}, \mathrm{Pb}$, and $\mathrm{Se}$ ) except $\mathrm{Hg}$ using inductive coupled plasma spectrometry (ICP). Post-injection concentrations of RCRA metals were compared with the pre-injection ground water samples. Mean concentrations of RCRA metals from the monitoring wells are presented in Tables 2 and 3. The concentrations of $\mathrm{Ba}$ and $\mathrm{Cd}$ in the monitoring wells inside the treatment zone were slightly elevated above the pre-injection levels and remained high through the eight weeks of monitoring. The concentrations of these cations were highly variable among the monitoring wells. The increased concentrations of these cations could be a function of cation exchange reaction with $\mathrm{K}$ and $\mathrm{Na}$ contents of the applied reductant. Although $\mathrm{Ba}$ and $\mathrm{Cd}$ levels were elevated early in the postmonitoring periods, they remained localized within the treatment zone. Post- injection concentrations of RCRA metals in the monitoring wells outside the treatment zone were similar to the pre-injection values. Data suggest that the applied reductant did not solubilize or mobilize any of the RCRA metals outside the treatment zone.

The distributions of $\mathrm{Cr}(\mathrm{VI})$ in post-injection soil cores are depicted in Figure 9. The data suggest that below the 4-foot depth from the ground surface, $\mathrm{Cr}(\mathrm{VI})$ in the treatment zone sediments ranges from 0 to $37 \mathrm{mg} / \mathrm{kg}$. Only one sample (PDS1,4 to 4.5 feet) from the downgradient treatment zone exceeded the $78 \mathrm{mg} / \mathrm{Kg} \mathrm{Cr}(\mathrm{VI})$ soil target concentration of the North Carolina Department of Environment and Natural Resources (NCDENR), risk-based Soil Target Concentration for Residential site. In contrast, at the same depth, sediment samples from the upgradient core (PDS-4) contain higher $\mathrm{Cr}$ (VI). Results suggest that the applied reductant was more effective in reducing $\mathrm{Cr}(\mathrm{VI})$ concentrations in the capillary zone in the downgradient direction than in the upgradient direction from the injection point.

\section{Summary and Conclusions}

Sodium dithionite was injected into the lower portion of the vadose zone to detoxify and immobilize $\mathrm{Cr}(\mathrm{VI})$ as a remedial strategy. The geochemical data from monitoring wells and the level of $\mathrm{Cr}(\mathrm{VI})$ in the sediment were used to evaluate the effectiveness of sodium dithionite as a reductant in remediating $\mathrm{Cr}(\mathrm{VI})$ at field conditions. Post-injection results suggest that sodium dithionite was effective in creating a targeted reduced zone in the site. The $\mathrm{Cr}(\mathrm{VI})$ concentrations in the ground water have been reduced to less than $0.01 \mathrm{mg} / \mathrm{L}$, which is well below the U.S. EPA and NCDENR Drinking Water Standards. Continued $\mathrm{Cr}(\mathrm{VI})$ reduction was seen 48 weeks post injection, indicating that an extended period of reduction is occurring. Nonmobile reduced structural iron within the silicate minerals present in the treated sediments may be con- 
tributing to long-term remediation of $\mathrm{Cr}(\mathrm{VI})$. Periodic monitoring of $\mathrm{Cr}(\mathrm{VI})$ in ground water and sediment samples confirmed the effectiveness of abiotic detoxification and immobilization of $\mathrm{Cr}(\mathrm{VI})$ by the applied reductant. No adverse effect on RCRA metals was observed during the post-injection monitoring periods. As a part of site remediation efforts, the use of sodium dithionite appears to be a viable option for a full-scale remedial approach for the source area in the electroplating shop at the U.S. Coast Guard Center.

\section{Acknowledgments}

The authors would like to acknowledge Dr. Carl Palmer and anonymous reviewers for their thoughtful comments on an earlier version of the manuscript, and the assistance of Cindy Paul, Mary Sue McNeil, and many other coworkers in conducing field experiments.

\section{Disclaimer}

Although the research described in this article has been funded wholly or in part by the U.S. EPA, it has not been subjected to the agency's peer and administrative review and therefore may not necessarily reflect the views of the agency; no official endorsement may be inferred.

\section{References}

Amonette, J.E., J.E Szecsody, H.T Schaef, J.C. Templeton, Y.A Gorby, and J.S. Fruchter. 1994. Abiotic reduction of aquifer materials by dithionite: A promising in-situ remediation technology. In Proceedings of the 33rd Symposium on Health and the Environment: In Situ Remediation: Scientific Bases for Current and Future Technologies, 851-882. Columbus, Ohio: Battelle Press.

Barlett, R.J. 1991. Chromium cycling in soils and water: Links, gap, and methods. Environmental Health Perspectives 92, 17-24.

Bartlett, R.J., and B. James. 1988. Mobility and bioavailability of $\mathrm{Cr}$ in soils. In Chromium in the Natural and Human Environment, ed. J. Nriagu and Nieboer, 267-304. New York: John Wiley \& Sons.

Eary, L.E., and D. Rai .1988. Kinetics of chromate reduction by ferrous ions derived from hematite and biotite at $25^{\circ} \mathrm{C}$. American Journal of Science. 289, 180-213.

Fendorf, S.E. 1995. Surface reactions of chromium in soils and waters. Geoderma 55-71.

Fruchter, J.S. 2000. In situ redox manipulation for treatment of chromate and trichloroethylene in groundwater. In Proceedings of Abiotic In Situ Technologies for Groundwater Remediation Conference, Dallas, Texas. EPA/625/R-99/012. Cincinnati, Ohio: U.S. Environmental Protection Agency.

Gan, H., J.W. Stucki, and G.W. Bailey. 1992. Reduction of structural iron in ferruginous smectite by free radicals. Clays and Clay Minerals 40, no. 6: 659-665.

James, B.R. 1996. The challenge of remediating chromium-contaminated soil. Environmental Science \& Technology 30, no. 6: 248A-251A.

James R.B. J.C. Petura, J.V. Rock, and G.R. Mussoline. 1995. Hexavalent chromium extraction from soils: A comparison of five methods. Environmental Science \& Technology 29, 2377-2381.

Khan, F.A., and R.W Puls. 1999. Reductive detoxification and immobilization of chromate present in soils. Hydrological Science and Technology 15, nos. 1-4. 138-144.

Komadel, P., P.R. Lear, and J .W. Stucki. 1990. Reduction and oxidation of nontronite reactive rates extent of reduction. Clays and Clay Minerals 37, no. 2: 203-208.
Palmer, C.D., and R.W. Puls. 1994. Natural attenuation of hexavalent chromium in ground water and soils. EPA/540/S-94/505. EPA/600/F-97/008. National Risk Management Laboratory, Ada, Oklahoma.

Palmer, C.D., and P.R. Wittbrodt. 1991. Processes affecting the remediation of chromium-contaminated soils. Environmental Health Perspectives 92, 25-40.

Paul, C.J., F.A. Khan, R.W. Puls, and J.A. Vardy. 1999. Characterization and in-situ remediation of chromium-contaminated soils and sediments at the USCG Support Center. In Proceedings of Conference 1999 Joint ASCE-CSCE Environmental Engineering Conferemce (EPA/600/A-99-023); 111-120.

Puls, W.R., D.W. Blowes, and R.W. Gillham. 1999a. Long-term performance monitoring for a permeable reactive barrier at the U.S. Coast Guard Support Center, Elizabeth City, North Carolina. Journal of Hazardous Materials 68, 109-124.

Puls, R.W., R.M. Powell, C.J. Paul, and D. Blowes. 1999b. Groundwater remediation of chromium using zero-valent iron in a permeable reactive barrier. In Field Testing of Innovative Subsurface Remediation Technologies, American Chemical Society Symposium Series 725, ed. M.L. Brusseau et al., 182-194. Cary, North Carolina: ACS.

Puls, R.W., and R.M Powell. 1992. Acquisition of representative ground water samples for metals. Ground Water Monitoring Review 12, no.3: 167-176.

Puls, R.W., C.J. Paul, D.A. Clark, and J. Vardy. 1994. Transport and transformation of hexavalent chrome through soil and into ground water. Journal of Soil Contamination 3, 203-224.

Sass, B.M., and D. Rai. 1987. The solubility of amorphous Cr(III)Fe(III) hydroxide solid solutions. Inorganic Chemistry 26, $2228-2232$

Yin, Y., and H.E. Allen. 1999. In situ chemical treatment. Groundwater Remediation Technologies Analysis Center technology evaluation report TE 99-01. Pittsburgh, Pennsylvania: GWRTAC.

\section{Biographical Sketches}

Faruque Khan is an environmental scientist with the Environmental Fate and Effects Division of the Office of Pesticides Program, U.S. Environmental Protection Agency (Ariel Rios Bldg., MC 7507C, 1200 Pennsylvania Ave., N.W., Washington, D.C. 20460; khan.faruque@epa.gov).He has an M.S. and a Ph.D.in soil science and water resources from Iowa State University. While at Iowa State, he conducted basic and applied research on the fundamental geochemical processes and properties of soils as they relate to critical problems and opportunities of natural resources management within the state of Iowa. In addition to his research, Khan supervised the Soil Survey Characterization Laboratory at Iowa State University. Prior to joining the Office of Pesticides Programs, Khan served as a research soil scientist, Subsurface Remediation Branch of the Subsurface Protection and Remediation Division of U.S. EPA in Ada, Oklahoma.

Robert W. Puls has worked as a research soil scientist at the R.S. Kerr Environmental Research Center of the National Risk Management Research Laboratory of U.S. EPA (P.O. Box 1198, Ada, OK 74820) since 1987 and recently became chief of the Subsurface Remediation Branch. He has a B.S. in soil science and natural resources from the University of Wisconsin, an M.S. from the University of Washington, and a Ph.D. in soil and water science from the University of Arizona. His recent publications have covered a range of topics including ground water sampling, colloidal transport in ground water, organic-metal-mineral interactions, the development and evaluation of in situ remediation techniques for soils and ground water, and metal and metalloid sorption-desorption reactions governing subsurface contaminant transport and transformation processes. 